Article

\title{
Energy and Water Policies in Chile, Two Different Endings with Implications in the Water-Energy Nexus
}

\author{
Roxana Bórquez ${ }^{1,2, *(D)}$ and Rodrigo Fuster ${ }^{3}(\mathbb{D}$ \\ 1 Center for Climate and Resilience Research (CR2), University of Chile, Blanco Encalada 2002, 4 Piso, DGF, \\ Santiago 8370449, Chile \\ 2 Department of Geography, King's College London, 40 Bush House (North East Wing), Aldwych, \\ London WC2B 4BG, UK \\ 3 Department of Environmental Sciences and Renewable Natural Resources, Faculty of Agricultural Sciences, \\ University of Chile, Avenida Santa Rosa 11316, La Pintana, Santiago 8820808, Chile; rfuster@uchile.cl \\ * Correspondence: rborquez@dgf.uchile.cl
}

Citation: Bórquez, R.; Fuster, R. Energy and Water Policies in Chile, Two Different Endings with Implications in the Water-Energy Nexus. Energies 2021, 14, 3286. https://doi.org/10.3390/en14113286

Academic Editors: Vincenzo Bianco and Nikolaos P. Theodossiou

Received: 13 April 2021

Accepted: 30 May 2021

Published: 4 June 2021

Publisher's Note: MDPI stays neutral with regard to jurisdictional claims in published maps and institutional affiliations.

Copyright: (c) 2021 by the authors. Licensee MDPI, Basel, Switzerland. This article is an open access article distributed under the terms and conditions of the Creative Commons Attribution (CC BY) license (https:/ / creativecommons.org/licenses/by/ $4.0 /)$.

\begin{abstract}
Energy and water have faced important levels of conflicts in the last 20-25 years in Chile. However, the way that they have been politically addressed in the last decade differs. These differences emerge from how these fields have been historically configurated, impacting on how the policy problems and policy options have been framed. Using thematic analysis of 93 interviews and documentary analysis, this article analyzes by contrasting two participatory processes which nourish the formulation of the energy and water policies in Chile in 2014-2015. It seeks to understand the factors that may influence why the development, impact and inclusion of new voices in public policies related to water and energy have been different, and how that can impact the water-energy nexus. Five factors emerge as determinants in this difference: structure of use, number of actors, governance and institutional framework, elite conformation, and legal framework. These factors impacted the policy processes and the scope of the policy outcomes, generating two different results: a long-term energy policy, and a water policy that did not survive the presidential period. Thus, the water-energy nexus is under pressure as a result of the tension between power structures, social responses to environmental issues and decision-making, environmental limitations, and climate change stressors, creating greater vulnerability and conflicts.
\end{abstract}

Keywords: water; energy; water-energy nexus; policy-making; participation; elites; policy process; unregulated market

\section{Introduction}

This article explores the energy and water governance in the transition from a dictatorial regime to a democracy, in order to understand the factors that may influence why the development, impact and inclusion of new voices in public policies related to water and energy differ in Chile, and how that can impact in the water-energy nexus.

The transition towards more participatory approaches becomes a highly complex process in post-dictatorial democracies because authoritarian legacies influence and may frame the policy-making, obstructing innovative and bottom-up approaches in developing policy instruments. Chile is a democracy in which authoritarian legacies are reflected in the transfer of decision-making dominance to the private sector in different fields that, in the past, were the responsibility of government. Those legacies were consolidated in democracy. However, local and civil organizations have come to play new roles in influencing and changing the political agenda. These areas are closely related to socio-environmental conflicts.

For decades, governments and their policies have been questioned due to their negative impacts on the environment, generating uncertainty and mistrust among citizens [1]. In 1990s and 2000s, many authors associated environmental concern with ideas of more 
deliberative and participatory forms of democracy. They recognized the role of this democratic practice as a mediator between socially constructed understanding and nature [2]. This trend has had a substantial debate around the value of participation and the notion of deliberative democracy [3]. In this context of democratization, society actors increasingly call for the inclusion of new voices into public policy, especially in complex social issues in order to create more legitimate policies that consider the needs of all the actors. Thus, democracy has occupied new spaces beyond the political sphere, representation and elections, creating new deliberative arenas.

In the Chilean energy and water sectors, civil society has demanded more attention/support from the state through public protests, social networks and the media. Against a background of social pressure, during the presidential campaign of 2013, two actions were promised: a National Energy Policy and the appointment of a Presidential Delegate for Water Resources who led the creation of the National Water Policy. According to the policy documents, both energy and water policies were developed through participatory processes. However, different strategies and methodologies were used with different outcomes and levels of success.

The national Energy Policy included one of the first participatory processes to design level for public policy in the Energy Sector in Chile. Academic experts played a central role in leading, facilitating and supporting the process, in a significant innovation that signaled a changing role for scientific expertise in policymaking processes. This process was developed in coordination between different departments within the Ministry of Energy and national universities, and involved the development of 205 workshops with diverse actors in different territories across the country.

In contrast, although the National Water Policy indicated that the policy was built after a participatory process where a wide range of actors participated, interviewees indicated they were not invited to develop a policy, but to discuss and identify the main water problems of their territories. It was not possible to quantify the number of workshops or the number of participants.

To date, after five years of implementation, the National Energy Policy (a long-term policy) annually reports its progress and is currently under a participatory update process. The impacts of the policy were immediate. For example, these included the reduction of energy prices, a diversification of the market and a significant increase in renewable energy, among others. In the report "Energy Policies beyond IEA countries, Chile 2018" the International Energy Agency [4] states that "the major achievement of the government has been to develop a long-term energy policy to 2050".

Conversely, the National Water Policy did not survive the change of the government coalition, after the presidential elections in 2017. Since its publication in 2015, there was no evidence of progress in relation to its objectives, it did not imply any institutional change or any impact in mitigating water problems that have intensified in recent years. Another proof of the lack of impact of this process is that the new government initiated in 2019 a new discussion process that incorporates the elaboration of a new long-term policy.

This study used qualitative research through case study methods. Two methods for collecting data were selected: interviews and documentary analysis. A thematic analysis of 93 interviews, a content analysis and a qualitative analysis of documents were carried out.

From the analysis of primary and secondary data, this piece of research identified five factors as drivers of these different policy outcomes and impacts. The first is the structure of use. Water is a localized resource in supply and demand, generally circumscribed to the basin from where it emerges. In contrast, energy, particularly electricity, is usually locally generated, but demand is at the national level. Therefore, local conflicts or problems impact at the national level. The second factor is the number of actors. The water sector is controlled by an undetermined number of actors, most of them localized regionally. The energy sector is controlled by a known number of actors localized mainly in Santiago, the capital. The third factor is governance and institutional framework. Energy has a better-defined institutional framework and its structure of governance fits better with the 
centralist style of governance in Chile. The fourth factor is the elite composition of energy and water sectors (who are part of those elites). The water sector is composed of a highly conservative, traditional elite, while the energy sector is composed of a more technocratic one. The fifth factor is the legal framework because the level of regulation of the water and energy markets determines how open they are to new state and citizen roles in the sectors. These factors impacted the policy processes and the scope of the policy outcomes, generating two different results: a long-term energy policy and a water policy that did not survive the presidential period. This disparity impacts the water-energy nexus.

The effects of these factors are important because energy and water conflicts have increased around the world, and the inclusion of new actors in policy-making has been a policy response to tackle those conflicts. However, policy solutions do not always have the expected outcomes because they do not analyze factors of different natures that constrained discursively open and participatory policy processes.

This article presents first the Chilean historical context, which determines how the energy and water sectors are framed. Later, material and methods are exposed. In the result section, the energy and water process are illustrated, analyzing the whole lifecycle of public policies. In the fourth section, discussion focuses on the factors identified as differentiators between the energy and water case, the role of social pressure, new public arenas, and participation in policy-making and on how these differentiators may affect the energy and water nexus. A final section of conclusion is laid out.

\section{Contextualization}

Chile was led by a right-wing dictatorship for 17 years between 1973 and 1989. The authoritarian legacy was pervasive, impacting many aspects of the economy, politics and society [5]. Firstly, many reforms were developed from the 1980s. Perhaps the best-known changes were in the economic model. Free-market ideas advised by the 'Chicago School' economists Milton Friedman and Arnold Harberger were implemented [5], reducing import tariffs, privatizing national industries and dismantling public institutions [6]. In 1980, authoritarian officials changed the Constitution, strengthening private and individual rights over social or common rights, and determining new codes and laws related to education, health, pensions, labor, mining, water, and energy, among others. As a result, education, health, pensions, transport service companies, agricultural and industrial enterprises, parts of mining companies, the granting of mining licenses, and electricity companies, among others, were privatized [7]. Secondly, the pact between the political parties and the former regime after 1990 determined a perpetuation of the economic model imposed by the dictatorship and the protection and maintenance of certain privileges of former officials [8].

The creation of the binominal voting system (two-party system) was another aspect of the pact. This system, incorporated in the Constitution change of 1989, restricted electoral choice and limited political competition [9]. This system was not based on a scheme of proportional representation, excluding parties outside the two major political pacts, "Concertación" (center-left) and "Alianza por Chile" (right-wing), and favored the Alianza, because although it received less votes, the calculation mechanism was such that those who obtain 34 percent of the votes take half the seats in parliament [9]. The impact of this system determined a limited legislative change, an avoidance of conflict, permanent search for consensus between the two coalitions, and lack of representation of other voices [5]. This system was changed. The parliamentary election in 2017 was the first election without the binominal system. This election included all Deputies and half the Senators. However, the Constitution, Codes or Organic Laws still, such the Water Code, need two-thirds of the votes of parliamentarians to be modified, which has meant that structural changes are very difficult to achieve.

The top-down tradition, non-proportional electoral system (binominal) and the neoliberal reforms have discouraged the participation of other actors in public policies [10]. The constitutional principle of economic freedom guaranteed the private sector the right 
to develop any economic activity and restricts government intervention in business [11]. Moreover, social participation in public policies was not considered. Government regulations were only developed in areas where the market could not work naturally due to monopolistic characteristics [12]. These legacies have had a huge impact on the Chilean democracy. This is a democracy in which the private sector has dominated decisions in different fields, but these are increasingly areas where local and civil organizations have come to play new roles in influencing and changing the political agenda.

In energy, the central role that the market played in determining planning in the sector, combined with the reduced role of the state and the non-binding role of civil society, highlights how closed and autonomous the energy sector was. The resolution of problems and decisions were delimited and determined by the private sphere, with some interactions with the government. Even when some non-binding channels of participation were used, the social sphere was (and has been in most of the cases) a spectator of the decision-making process for its territories and at the national level. This situation has stressed the relation between communities and the government and private companies.

In water, the evolution of the sector is directly related with policies imposed in dictatorship, with a high level of conflict. For example, before the 1980s, water was managed with land; the state granted users a right to use water by defining priorities among different uses, and management decisions were defined by users on a one-personone-vote basis [13]. However, in 1980, the Chilean Constitution created a framework of strong private rights, and then the 1981 Water Code changed the way that water was used. While water was first recognized as a national public good, use rights were (and are) recognized as property rights in the Constitution, perpetual and inheritable in nature, separating water ownership from land ownership [14]. Priorities of use were eliminated since the objective of the new code was to use water in the most economically efficient manner [15]. Thus, the market was established as the mechanism for distribution among the different uses and users without intervention by the state [16]. The logic was "that the market would enable the reallocation of scarce water to higher value uses, as users would be incentivized to sell water if they did not need it" [14]. The management decisions are defined with proportional votes to the quantities of water rights owned by each of the users [16].

\section{Materials and Methods}

The study used qualitative research through case study methods. Two methods for collecting/generating data were selected: interviews (Table 1) and documentary sources. A five-month period of fieldwork took place from January 2017 to May 2017 in Chile. Semi-structured interviews were used through a guide with questions based on specific dimensions of analysis, which explored the whole lifecycle of public policies from the emergence of the issue, policy problem and agenda-setting to the participatory process and initial implementation.

Table 1. Distribution of interviewees by type of actor.

\begin{tabular}{ccccc}
\hline Type of Actor & Total & Energy & Water & Shared \\
\hline Decision Maker & 17 & 11 & 6 & 0 \\
Policy Maker & 20 & 13 & 8 & 1 \\
Academia & 21 & 17 & 7 & 3 \\
Civil Society & 18 & 13 & 11 & 6 \\
Private Sector & 17 & 9 & 10 & 2 \\
\hline Total & $93^{1}$ & 63 & 42 & 12
\end{tabular}

${ }_{1}^{1}$ Note: the total sum in energy and water is more than 93, because there are sharing interviewees, that is, interviewees who have been connected with both water and energy processes.

A thematic analysis was developed in order to analyze systematically all the data corpus. Ninety-three people were interviewed. Twenty-five codes were organized in six 
clusters of themes, two of them related to the process and its political context, and the other four associated with the theoretical framework.

Texts/documents cover a broad range of different sources: minutes of sessions, reports, official documents deriving from state, official documents deriving from private sources and mass-media outputs. The data collection started in January 2015. A content analysis of official documents that emanated from the energy process and later activities (Workstream reports, the Roadmap, the Energy Policy and the Energy Route) was undertaken. A qualitative analysis of documents was carried out for other types of data sources collected in order to rebuild the processes and triangulate information.

\section{Results}

The results section of this article emerged from the analysis of interviews and documentary analysis. It focuses on each one of the cases in order to present their particularities across the lifecycle of the public policies: the emergence of the conflict and configuration of the public problem, agenda-setting, the process, policy outcomes and implementation.

\subsection{The Energy Process}

From the latter 1970s, the Chilean electric capacity was heavily based on hydropower, but from the late 1990s, there was a growing use of pollutant-fossil sources, such as gas, coal and latterly oil [17]. Following the restoration of democracy, fast Chilean economic growth generated a high demand for electricity and new generation capacity, which quadrupled between 1990 and 2010 [17]. In terms of ownership, the Chilean electricity market was highly concentrated. For example, four companies controlled $95 \%$ of the market and $90 \%$ of the generation capacity in 2005, decreasing to $80 \%$ in 2015 [18]. In terms of electricity demand, figures show that industries and mining consumed $60 \%$ of the electricity, while residential and commercial consumed $29 \%$ in 2014 [19].

\subsubsection{The Emergence of the Conflict and Configuration of the Public Problem}

The energy policy process emerged as a way to unlock the energy sector, where a series of crises began in the 1990s as a result of operational and investment decisions made by the private sector and escalated to massive protests and demonstrations against generation projects in the late 2000s and the early 2010s. The level of discontent was growing not only in intensity, but in scope. Protests and legal actions were the strategy of local communities and the environmental movement to stop or delay projects [20]. Mobilizations against mega-projects occurred at Campinche (in 2009), Barrancones, Los Robles and Achibueno (in 2010), HidroAysén (2009-2011), Castilla (in 2011), Alto Maipo (in 2014) and El Campesino (in 2016), among others [19].

HidroAysén was the most emblematic. It was led by the two largest generation companies: ENDESA (later Enel) and Colbún. It would be constituted by five dams in two rivers of the Aysén Region, with an expected annual generation of 18,430 GWh of electricity, which would have represented 28\% of Chile's annual consumption in 2012 [21]. This project became a focus of social pressure on political decisions. The level of conflict was so serious that it was transformed from a project with local environmental impacts to a social, environmental and political national problem. Both the Bachelet (2006-2010) and Piñera (2010-2014) administrations tried to elude a final decision about the approval or not of generation projects by the System of Environmental Impact Assessment (SEIA). Thus, the HidroAysén project faced resistance, but also caused the 'Chilean model' to be questioned [22]. The decision to end the project would have been unthinkable in the previous decade. However, on 17 November 2017, Colbún and Enel formally announced the total closure of the project and a waiver of the water rights [23].

Before 2013, the government response of different administrations was reactive. They created advisory groups represented mainly by experts in energy, policy-makers, the private sector and academia, excluding other points of view (environmental NGOs). These groups lacked legitimacy. The government was also almost absent in public arenas created 
in order to debate and find solutions to the energy crisis, such as Energy Scenarios, one of the most important arenas that influenced the energy process (see the following quotation):

"We must recognize the great absence in those conversations [Energy Scenarios] were the government agencies, people from the Ministry of Energy sat sometimes, but in a very reticent way, that means they never were really there, it was very difficult." [former member of Energy Scenario]

For the Chilean government, the energy conflict was a conflict among private actors, therefore its solution should be found by those actors. This follows the neoliberal logic imposed in the dictatorship and consolidated in democracy, restricting government intervention in the market. The government considered energy as technical issues, which could only be resolved technically by electrical engineers.

The political cost of the government absence was high, the national environmental framework demonstrated its limitations and weakness, the level of acceptance of the government fell quickly, and social protests were growing up. As a result, the Minister of Energy was changed five times in four years from the creation of the Ministry of Energy at the beginning of 2010: Ricardo Raineri (11 March 2010-14 January 2011), Laurence Golborne (16 January 2011-18 July 2011), Fernando Echeverría (18 July 2011-21 July 2011), Rodrigo Alvarez (22 July 2011-27 March 2012), and Jorge Bunster (3 April 2012-11 March 2014).

Crises showed the weaknesses of the Chilean energy system, the deficiencies of Chilean regulatory governance, the dangers of a less diverse energy matrix, and a lack of long-term planning. The political response to the crises was reactive, making changes in the face of legal loopholes and disputes, which partially solved weaknesses [24].

\subsubsection{Agenda-Setting}

Energy-related subjects followed the same pattern as the historical context of participation in policy processes in Chile. Policy instruments were created by experts and elitist advisory groups, and regulations were made in areas where the market could not work under competitive conditions. Although many short-term policy instruments were made in order to solve the loopholes that the energy issues showed, they were focused on resolving particular problems and did not focus on the energy system as a whole.

Although Energy Scenarios sat with polarized groups, showing that the dialogue was possible, and put energy in the public agenda, it did not unlock the energy conflict. A major impact required the involvement of the state in order to unlock the conflict, generate political changes and re-mobilize the energy sector. This, in a country which was the pioneer of electricity market reforms [25] where privatization of state-owned companies was one of their key components [26]. Fifteen years passed from the time of the first energy issue before the government decided to develop a participatory long-term policy.

The awareness that energy was a strategic subject and the level of stagnation of the sector generated by the social rejection of energy projects are part of the key factors which determined the political problem and framed the political agenda. A carbonized electrical matrix and very high energy prices were a demonstration of this. For example, the electricity bill paid by families increased 20\% between 2010 and 2013, and industries were facing one of the highest electricity prices in Latin America [27]. Different policy-makers, decision-makers from the government and senior executives of the private companies pointed out their perception during the interviews, which are in the same vein:

"The idea comes from the realization that the energy issue is a long-term strategic matter. It is a subject that we must face as a State policy". [CODE 001, Decisionmaker, government agency]

"It had been a social requirement for a long time: to incorporate citizens within the processes of the definition of the energy policy at different levels. Perhaps the most evident thing was from local communities and environmentalism, but there was also a strong pressure from users, industry and mining because they wanted more stability. There was a stagnation of energy projects and a more 
empowered society which would not allow others to decide about projects in their territories without taking them into account. Therefore, somebody had to take actions and reconcile positions, to think about the welfare of the country". [CODE 027, Policy-maker, government agency]

"The Government understood that a subject as sensitive as the electric matrix of the country has to have citizen participation. This need was born because of a constant opposition of citizen groups to energy projects. Therefore, it was necessary to find validation mechanisms for building generation plants." [CODE 074, the private sector]

In 2013, the government program of Michelle Bachelet, President of Chile between 2014 and 2018 (second presidential term), established a commitment to develop a participatory planning process for long-term energy policy: Energy 2050. The aim was to build a common vision for the future of the energy sector, gaining social, political and technical validation [28]. The process represented the first participatory process where a wide range of actors have participated in the initial design of a public policy for the energy sector in Chile. Additionally, this was the first time where academia was called upon to support and lead a large participatory policy process in energy and any other related environmental subject. This was a significant innovation, which signaled a changing role for scientific expertise in energy policymaking processes.

Some important decisions were made in the initial stage, showing the government mandate of the new administration. Four are identified. Firstly, the inclusion of the topic in the government program of Bachelet during the presidential campaign in 2013, which recognized the need for the state to assume a proactive role in guiding the development of the sector, the lack of regulations and land-use planning, the weaknesses of government agencies at institutional level, and others issues [28].

Secondly, President Michelle Bachelet appointed Máximo Pacheco as the head of the Ministry of Energy (or Minister of Energy). He had a history of 40 years as a senior executive of large companies and important networks, and therefore shared a common language with the private sector. The following quotation extracted from the book Revolución Energética (Energy Revolution) by Pacheco [29] shows that although the massive protests and polls showed that social discontent and the level of stagnation was recognized transversely, the private sector was seen as the actor that the government had to deal with. For that reason, the leadership of the process was given to Pacheco, who was part of the private sector, although not part of the energy sector.

"I perfectly remember the emphasis she placed [President Michelle Bachelet] on the relevance of solving the high cost of energy ( . . ) it was the issue that most concerned the business community. She highlighted my knowledge of how markets operate and the dialogue that I could establish with the private sector to reach solutions". [29]

Thirdly, the level of conflict opened the opportunity to act. The continuing protests against generation projects created an environment of tension that helped to justify the need to include those voices in the dialogue. Discursively, the government used civil society expectations as a key engine of the 'needed' reframing of the role of state. For instance, in the policy document, they assert "Chilean society expects a planning and leadership role from the state that considers all interested parties in the definition of a solid and consistent strategy that guides the market" and continually use the concept of 'social validation' together with political and technical validation as a key factor for a successful long-term energy policy [12]. Therefore, the strategy of the government was to open the discussion to other actors and take a political definition, focused on participation and the role of citizens, as the following quotation shows.

"The strategy to develop an open and collaborative participation had relation to expand the field to other actors. (... ) The electrical context made it easier for the actors to sit at the table because we were under a crisis for many years. The 
actors, consultants and companies, said, 'we have blocked so many regulations, but now we have the opportunity to support it'. I think that actors had a bit of fatigue, they wanted to stop being "The Ugly Duckling' of the Chilean economy". [CODE 007, decision-maker, government agency]

The fourth important decision regarded the budget for the process. Although it is difficult to quantify the amount of money spent, some of the decision-makers interviewed recognized that it was an expensive process compared with other similar initiatives, which shows the government's interest in the implementation of this process.

To sum up, four decisions were highlighted as key: the inclusion of energy as a key topic in the Bachelet's presidential campaign; the appointment of a recognized businessman as the Minister of Energy; the decision to open the discussion to new actors; and the budget given to the process. Although these decisions did not ensure a successful process, they determined a strong involvement of the government beyond the solution of specific problems, changing its strategy from intervening to solve specific problems, as was usual, to developing a participatory long-term policy.

Once the government took office, the President gave 100 days to present a proposal guide of action for her administration. To achieve this, the Ministry decided to invite over 100 stakeholders to discuss energy topics. The Energy Agenda was a document formulated by the Ministry of Energy that emerged from that discussion. The discussed topics configured the key aspects in the participatory process and the four-year administration program beyond the process.

\subsubsection{The Process}

From the Agenda, the Energy 2050 process began. Three stages shaped the process (See Figure 1). As a first stage of the process, 10 different Workstreams addressed different energy topics: Innovation, Indigenous Affairs, Shared Ownership \& Spatial Planning, Energy Efficiency Law, Heating \& Firewood, Transmission Law, Non-conventional Renewable Energy, Gas, Hydroelectricity, and Thermoelectricity. Every Workstream was led by different academic teams and divisions of the Ministry of Energy. This allowed the Ministry to diversify the work and reach different regions, developing the process at the same time in different locations. More than 3500 stakeholders of different regions participated in the 205 sessions distributed heterogeneously. Outputs of this stage were the bases of a second stage of the process, the Advisory Committee. This committee was comprised of 27 actors (academia, NGOs, the private sector and policy-makers) who represented different advocacy groups. From this second stage, the Roadmap 2050 report emerged.

Later, in the third stage, a deliberative poll took a random sample of the public: 1362 people were surveyed and 212 people participated in a deliberative forum [30]. The Ministry of Energy took the Roadmap 2050 report and the results of the deliberative poll and elaborated the Energy Policy. A public consultation of the policy was developed. In total, 420 people were part of the workshops, and the virtual platform received 400 comments [31]. The Minister presented the new Energy Policy in December 2015 and then began the dissemination and implementation stage. 


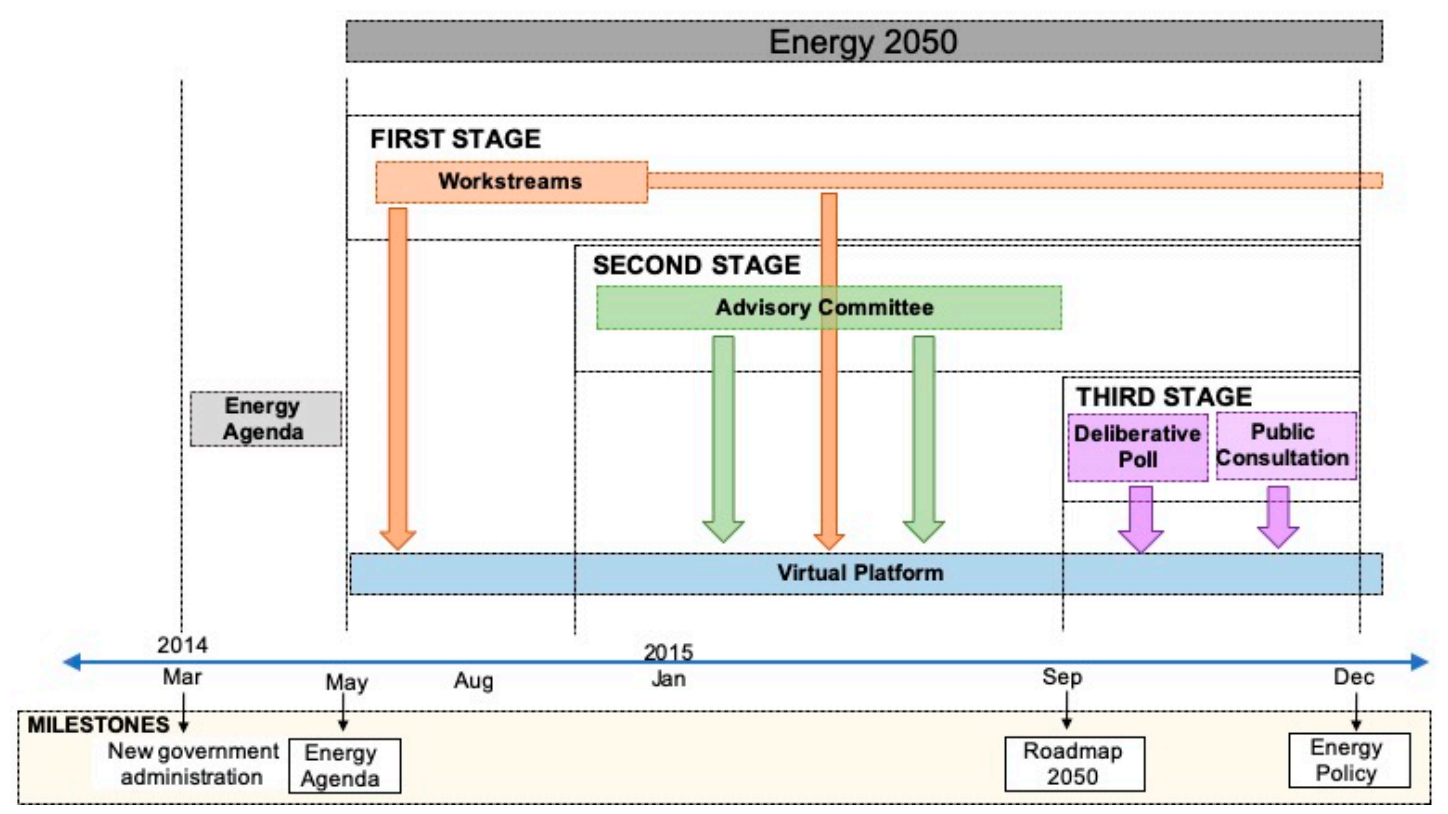

Figure 1. The Energy Policy timeline.

\subsubsection{Policy Outcomes}

The policy itself was built based on the input from the process, where the Ministry of Energy decided which aspects to include and which aspects not to include. This means that the outputs of the process were not binding. However, a content analysis carried out in this study showed that the Roadmap and the Energy Policy have an $80 \%$ match among actions. That is, 125 of the 155 courses of actions of the Roadmap are included in the policy document. The analysis of interviews also showed that the Energy Policy was at least legitimate for the actors who participated in the process or actors very close to the energy sector. In terms of continuity, data shows that although there was a change of perspective related to the role of the state and the Energy Policy has been downplayed by the new administration, the level of validation of the policy among stakeholders acted to prevent a radical change to energy policy under the new Piñera government (2018-2022). Civil servants also played a role in this continuity because they continued to implement policies and measures, trying to keep coherence between actions of the policy and the ones proposed by the new administration. Additionally, it is also shown how this policy process was not an isolated activity, but a part of a broader institutional change in the Ministry of Energy policy-making, triggered by an internal political struggle.

\subsubsection{Implementation}

The energy scenario post-2013 was reconfigured and market signals were immediate. For example, while in 2013 four electrical supply tender processes failed to attract bids, and the price peaked at USD 135.92/MWh with the participation of two generators [32]. In the 2015 auction, prices dropped to USD 79.54/MWh and 38 offers were made as part of the tender process, where $66.5 \%$ of the new projects were solar and wind [4]. In 2016, the number of offers rose to 84 and the average price dropped to USD 47.6/MWh [4].

In terms of non-conventional renewable energy, in 2019 total energy generation (1170 GWh/year) was four times greater than in 2014 (281 GWh/year) [33]. In fact, Chile ranked fourth in attractiveness for renewable energy investment in 2015 in Ernst \& Young's RE Attractiveness Index [34], and first in 2018, according to the Energy Finance Climatescope 2018 by BloombergNEF [35]. These positions were unexpected before 2014.

The Transmission Law, formulated as part of the process, also had an important impact on the sector. The International Energy Agency [4] highlights that this law also enhanced the role of the state "in energy planning and expansion of the transmission 
system". This change gives the Ministry of Energy and the National Energy Commission (CNE) new roles.

In January 2018, the Ministry of Energy and the Association of Generation Companies agreed to phase out coal power generation unless they have carbon capture and storage technology or other equivalent technologies [36]. In June 2019, the main four companies (Enel, Engie, Colbún, AES Gener) and the Ministry of Energy signed an agreement to withdraw coal-fired thermopower plants [37]. Another achievement was the law that decreases the electricity tariff of resident consumers in places close to the energy generation sources.

If we look at the Energy Policy as a catalyst of the Chilean Energy Transition, it would be necessary to analyze it in its totality because an energy transition cannot be reduced to the increase of renewable energy, the decrease in prices and the increase in competitors, mainly focused on electricity. Energy transitions are as technical as political processes, which involve changes/transformation in technological features, infrastructure and power, social and cultural relations [38]. However, all these changes catalyzed by the policy positively impacted an energy system that was stagnant before 2015. Other aspects, such as Energy Efficiency, Shared Ownership and Spatial Planning, and location of new infrastructure remained unsolved. They could not be successfully addressed by the Energy Policy.

\subsection{The Water Process}

In the policy domain, the post-dictatorship era has seen the development of four instruments related to water: National Water Policy (1999), Water Code modification (2005), National Water Strategy (2013) and National Water Policy (2015), as well as a number of local or regional processes and international pressure (OECD mainly). International organizations such as the World Bank and OECD have made several recommendations to the Chilean governments in order to improve the water system, including aspects such as the integrated river basin management, conflict resolutions, protection of vulnerable groups and ecosystems, among others [39,40].

Under the Water Code, water user organizations (WOUs) are the ones which manage water rights at the watershed scale. WOUs are not under government administration, they are private and decentralized organizations that resolve disputes among their members regarding the use of water rights [41]. In these organizations, users with more water rights have more votes when decisions need to be made. This has meant that a small group of users dominate decisions of their organizations. Farmers have historically been the main water users in Chile, and therefore it is they who decide on water issues in their basins, with a minimum intervention of government agencies [16]. For example, in 2014, 73\% of water extracted was for agricultural use [42].

\subsubsection{The Emergence of the Conflict and Configuration of the Public Problem}

In Chile, the current conflicts of access to water are structurally linked to the management model established by the Water Code [43]. This model focuses water allocation on supply and demand criteria [43]. Bauer [44] identifies four types of water conflicts in Chile: (A) river basin conflicts between multiple users, where hydropower is often the main driver; (B) overexploited groundwater systems; (C) socio-environmental conflicts where water issues are central (e.g., large mining and hydroelectric projects); (D) political and ideological conflicts. We would add two other river basin conflicts, one related to illegal extractions, and another with the over-granting of water rights. There has been an over-granting in 117 aquifers in Chile [45]. This means that the General Water Directorate (DGA), the main government institution for water rights and administration, has granted more water rights than the availability of water in those basins.

In 2015, the National Institute of Human Rights (INDH) published the book "Socioenvironmental conflict map". It identified 118 socio-environmental conflicts around the country, where $55 \%$ of those conflicts were related to water issues, half of them (31 conflicts) associated with conflicts between communities and mining companies, and a third (18 conflicts) 
related to conflicts shared with energy [46]. Additionally, the situation of water scarcity is severe in some areas and regions. Currently, around 400,000 people are supplied through cistern trucks, distributed in 13 of the 15 Chilean regions [42].

Many academics, politicians, NGOs and international organizations claim for changes in the legal framework [44]. One of the main claims is that the institutional capacity of the Chilean model (and the model itself) is unable to tackle water conflicts [44]. However, reform attempts have taken decades and have not changed the essence of the Water Code in the 30 years of post-dictatorial democracy. The debate about those modifications to the Water Code lasted 13 years. In 2005, the reform to the Code was approved, but the scope of those reforms narrowed from its original proposal in 1992 due to strong political opposition of conservative parties and the private sector [14]. A non-use fee, the need for a statement of justification for new rights, sanctions to illegal extractions, ecological minimum flows for non-exhausted sources and new regulations to groundwater were part of the main changes [14]. However, Bauer [44] asserts "the Water Code's core principles remained intact" and points out how water conflicts have been worsened, becoming "more widely spread throughout the country, more entrenched and entangled, more complex and multi- sectoral, and more closely tied to energy and environmental conflicts".

All these conflicts have generated a decade of an emerging civil claim for the nationalization of water [47]. Civil society organizations have created several platforms around water injustice [47]. There is a general perception that the current system favors the interests of large corporations over the needs of regular citizens [48]. Mining and energy companies are part of these large corporations [48].

There have been many attempts to develop participatory initiatives to improve water management and governance, mainly at the regional level. In 2011, through a private initiative, the Water and Environment Roundtable was created, with the participation of the private sector, academia, civil society and some government institutions. However, the agricultural sector originally did not want to be part of it. Additionally, in 2016, a group of actors created Water Scenarios, emulating the experience of the Energy Scenarios, aiming to achieve water security in Chile by 2050. This initiative is conformed of private companies, academia, civil society organizations, and government agencies. It is still a work in progress.

\subsubsection{Agenda-Setting}

In the presidential campaign, Michelle Bachelet promised to appoint a Delegate for water resources during the first 100 days of government. Thus, Reinaldo Ruiz was appointed on 31 March 2014 by a Presidential Decree. In the text of the Presidential Decree it was indicated that the position of Delegate was created because it is a duty of the state to promote sustainability, management and the common good and, it is necessary to review public policies due to challenges of water issues and scarcity [49]. Reinaldo Ruiz is an economist who was national director of the Office of Studies and Agrarian Policies and then Undersecretary of Agriculture during the first government of Michelle Bachelet.

The position of the Delegate was housed in the Sub-secretary of Internal Affairs, belonging to the Ministry of Internal Affairs and Public Security. The role of the Delegate was to advise the President, coordinate and support policies and actions among ministries and public services, and formulate plans, programs and actions related to water resources management in order to face the drought that affects large areas of the country [49]. It is important to highlight that the Ministry of Internal Affairs and Public Security does not have institutions related to water issues, which are situated in other ministries such as Public Works, Environmental, and Agriculture, among others. The justification of this was to find an integral vision to look at water issues because more than 40 governmental institutions have some attribution related to water. 


\subsubsection{The Process}

The text of the National Water Policy indicated that its formulation emerged from a participatory process through "Mesas Territoriales del Agua" (Territorial Water Tables). These Water Tables were workshops in different territories where different actors participated [42]. According to the policy document, participants of these workshops were linked to water use. Among those mentioned are: farmers, mining companies, organizations of water users, canal associations and supervisory boards, leaders of associations of rural drinking water (APR), academics, lawyers, organizations of indigenous people, associations of rural municipalities, environmental groups, associations of sanitary companies, NGOs, parliamentarians, representatives of international organizations and others [42].

Interviews revealed that there was a process of participation, but this process was not necessarily connected to the policy itself. The discussion process at the regional and national levels was not with the aim of creating a policy. The discussion was focused on setting up problems related to water. Water Tables were developed in almost all the Chilean regions. Some of them were conformed only of civil servants. Seminars were developed at the national level. This means they were informative. No actor recognized his/her participation in a policy process at the regional level. Some regions were more active than others, but the focus was only regional.

There is not much information about the water process itself, but it was possible to find some official documents where the Presidential Delegate and the President of Chile explained the work done and official information that shows staff recruited to support the Delegate. In the annual presidential discourse in 2015, the President gave a report on the most important activities of the government during 2014, where she mentioned the creation of 10 Territorial Water Tables (Atacama, Coquimbo, Valparaíso, Metropolitana, Maule, Biobío, La Araucanía, Los Lagos, Los Ríos y Aysén) with participation of private and public actors [42]. Then, a report made by the Presidential Delegate to the Chilean Parliament mentioned the creation of 14 Territorial Water Tables, firstly, made by civil servants and then including other actors [50]. In addition, he emphasized that diverse actors were involved in the National Water Policy [50]. The Ordinance 10,666 indicated that 1200 meetings approximately were held by the Delegation [51]. Unlike the previous year, in 2016, the President did not mention the water policy (released in 2015) in the annual presidential discourse, and only a few mentions in other accountable reports from the government were made [52].

The official information was contrasted with information given by informants and information found in the news. Table 2 shows the regions that developed workshops covered by the media. Furthermore, the media showed that the objective of the Territorial Water Tables was to solve regional problems related to water and scarcity, not to provide inputs for the policy. Except in the Atacama region, the activities appeared to be meetings or seminars more than structured workshops and some of them were meetings solely for the public sector, not attended by other types of stakeholder. 
Table 2. Workshops according to date informed by media.

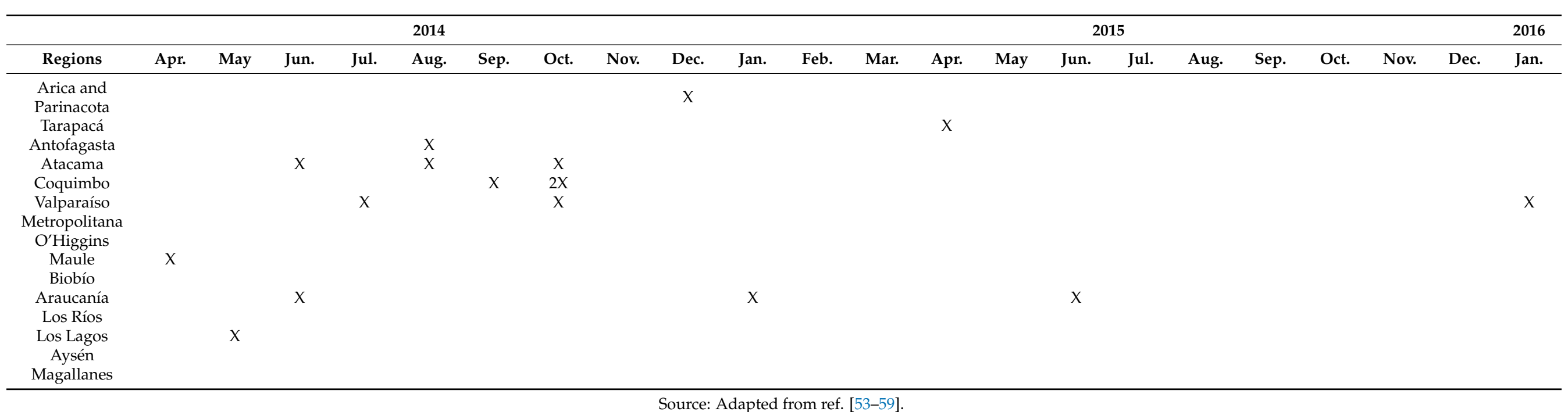


The perception about the water process is clear and shared by almost all interviewees: there was not a participative process to develop the policy. There were mainly informative seminars, some of them consultative at the national level. There were regional "water tables", but they analyzed regional problems and did not formally provide input for the national policy. Moreover, some coordinators recognized that the policy was built in parallel.

The Atacama Region was the only place identified by informants where there was a structured process, with formal and regular meetings, documentation and active participation of diverse actors: universities, the private sector, social organizations and government. The Atacama Region started a formal Regional Water Resources Advisory Council (CARRH) and Strategic Regional Program of Sustainable Watersheds (PER). These processes included participatory workshops. It is important to highlight that according to policy makers from the most important national water institution, the General Water Directorate (DGA), the institution was not part of the process due to internal conflict between the Delegate's role and the role of the DGA. It seems to be the result of power conflicts, because, until the creation of the Delegate's role, the DGA was the institution which created policies related to water in the country.

The conflict between the DGA and the Delegate is not isolated. In the recent discussion on the Climate Change Bill in the Environmental Commission of the Senate in the Chilean Congress, the Senator for the Atacama Region, Rafael Prohens, brought to light the difficulties the regional government faced because the DGA did want to validate a watershed study made by another government agency with regional funds [60].

\subsubsection{Policy Outcomes}

The aim of the National Water Policy was to "guarantee to current and future generations, the availability and access to water in adequate quality and quantity standards through the rational and sustainable use of water resources, prioritizing human consumption in the first place" [42]. The Policy has 13 guidelines organized in four axes: (1) the state as a responsible and participative agent; (2) measures to face the water deficit; (3) regulatory framework for water resources; and (4) strengthening the participation of social organizations. The policy document also incorporated a plan to tackle water scarcity. Unlike the Energy Policy, a comparison between topics discussed in the process and the policy document cannot be done.

\subsubsection{Implementation}

Among the actions of changing regulatory framework, it proposed a change in the Constitution in order to declare water as a national good ("a common good collectively managed by its local users" [44]) for public use and as a human right, and a new reform of the Water Code. The attempt to declare water as a national good for public use in the Constitution was rejected by the Senate, although 26 senators voted in favor and only 12 against because the Constitution, Codes or Organic Laws, such the Water Code, still need two-thirds of the votes of parliamentarians to be modified. The reform of the Water Code has been under discussion in Congress since 2014. The only bill approved by the Chilean Congress in 2017 is the Law 20,998, which regulates the rural sanitary services.

The aim to guarantee the availability and access to water remains unachieved, along with the plan to tackle water scarcity. Moreover, problems have gotten worse. Additionally, proposals about the strengthening of public institutions linked to the management and administration of water resources were not carried out.

In 2019, the new Piñera administration (2018-2022) created a National Water Table. Among its objectives, it seeks to formulate a long-term policy. This is enough evidence to exemplify the lack of impact, legitimacy and continuity of the Policy released in 2015. That table is conformed of 26 representatives of the government and the private sector, only one representative of civil society organizations and academia is not represented at all [61]. 
The water sector has been unable to unlock conflicts and discuss crucial issues, such as the human right to water, which is not granted in the Chilean Constitution. However, a window is open because Chile is changing the Constitution, and one of the central claims of actors is to incorporate the human and ecosystem right to water. Likely, this new Constitution will change the legal framework in which the water sector has moved over the last 40 years. For example, 81 of the 155 elected members to write the Constitution signed a commitment to include water as a human and ecosystem right.

\section{Discussion}

This study shows that although energy and water are key resources for the development of a country, both have faced high levels of socio-environmental conflicts in the last 10 to 15 years in Chile, and they both received international recommendations on changing institutional structures of the sectors, the two policies were contrasting in terms of the process, policy outcomes and impacts.

This article illustrates that the water sector has experienced more difficulties, intense negotiations and conflicts between politicians, entrepreneurs and citizens. A reflection of this is seen in the unsuccessful attempts to create a program of integrated river basin management or to resolve conflicts between farmers, between agriculture and mining and between indigenous and forestry/mining companies.

Diverse factors emerge as differentiators when an understanding on why two policies made by the same government, with a similar mandate to address key national topics finally ended up with different impacts. Based on the analysis of this study, five factors are identified and proposed in order to contribute to better understanding constraints and facilitators that the energy-water nexus faces in Chile, and whether this could impact the transition to sustainable energy.

\subsection{Factors}

In this section, the five factors are treated with different emphasis because some of them need an extended justification.

\subsubsection{Structure of Use (Where Is the Resource Extracted? Where Is the Resource Used?)}

Water is a localized resource in supply and demand, generally circumscribed to the basin from where emerges. In contrast, energy, particularly electricity, is usually locally generated, but demand is at the national level. Therefore, in energy, local conflicts or problems impact at the national level. This has impact on the regulatory framework, which is more centralized for electricity than water $[40,62]$.

\subsubsection{Number of Actors Who Control the Sector}

The water sector is controlled by 192,000 users [63], distributed across the country, organized by basin or regionally. Although energy projects are distributed across the country, owners or headquarters of the companies are mainly based in Santiago, the capital, and the sector in is controlled by a known number of actors.

\subsubsection{Governance and Institutional Framework}

Two aspects are analyzed: (1) level of governance: national or regional and (2) institutional framework. In terms of governance, Chile is a centralized country. Decisions are made in the capital, Santiago. Regions are administrators of the national mandates. Ministries have offices in the different regions, but they are comprised of a small group of professionals. If the structure of governance of water and energy are analyzed, the water sector fits better in a regional or watershed structure of governance [40]. In this structure, government agencies are weaker. In contrast, decisions in energy fit better in a centralized structure because the energy companies have their main offices in the capital, although the energy generation is produced locally. 
Secondly, energy has a better-defined institutional framework: The Ministry of Energy, which makes public policies, the National Energy Commission, which regulates, and the Fuel and Electricity Superintendence, which inspects. In water, 43 agencies are involved in water management in Chile, with a very diverse nature and hierarchy, ranging from private organizations formed by direct water users, different Public Ministries and their subdivisions, courts of justice, among others [64]. This diversity of institutions has led to problems of duplication and gaps in functions [64].

The interviews have also shown that some conflicts emerged at the institutional level between the DGA and other government agencies. This is another edge of the governance and institutional framework factor that is related to inter-institutional power relations that need further research. It seems that policy- and decision-makers from the DGA think that they are the only ones with authority to talk about water at the institutional level. This can be observed at the national and regional level.

\subsubsection{Elite Conformation (Technocratic Versus Traditional Elites)}

Elite theories have strongly argued that in any society there are minority groups of the population who play an influential role in political and social affairs [65]. The historical evidence is consistent with this argument and shows how privileged minority groups have dominated the rest using diverse strategies, mainly by coercion or persuasion [66]. This is a political and economic domination that potentially undermines the effectiveness of institutional reforms [67]. Therefore, who comprise the elites matters in any context. This is intensified in Chile by the fact that the constitutional principle of economic freedom guaranteed the private sector the right to develop any economic activity and restricts government intervention in business [11]. Therefore, the economic elites have dominated decisions in many fields, including energy and agriculture, relegating the role of public policies to promoting economic efficiency, which meant generating competitive conditions or emulating those conditions through regulations [12].

We argue that the different conformation of economic elites in energy and agriculture is one of the factors that have framed how these sectors began or did not begin to move the frontiers of what was feasible. In the post-dictatorship period, the energy policy domain has been more dominated by a technocratic elite than the water policy domain, which has been more dominated by a traditional elite. For this reason, although the technocratic elite is focused on technical decision over other points of view, it has been influenced by new science trends, more oriented towards sustainability and knowledge democracy. Conversely, the traditional elite that comes from colonial times is reluctant to change and lose power that it has held for centuries. This has allowed a more inclusive and open process in energy policy than in water policy.

In its study about human development and power in Chile in 2004, the United Nations Development Program concluded that "Chilean elites are dealing with a dichotomy between following the modernity in economic development-success in innovating-and being traditional and conservatives in their social values and orientations" [67]. This dichotomy is observed between elites in energy and agriculture.

The traditional elite in Chile is deeply rooted in the agricultural sector, a traditional economic sector that controls $73 \%$ of the country's water. Carrière [68] study on elite cohesion and conflict showed how land ownership is a status symbol in Chile from colonial times, occupying economic and political arenas and being recognized as the Chilean ruling elite in the 1970s. Currently, this traditional oligarchy associated with agriculture has maintained its status [68]. Particularly, one of the main institutions, the Sociedad Nacional de Agricultura (SNA) (National Society of Agriculture) has had particular access to decision-makers at all levels due to family and social ties with the traditional elites [68]. Carrière [68] also illustrated the role of the SNA in preventing government from extending labor and welfare legislation and pressuring for achieving policy instruments at their own convenience. 
The energy sector has been more dominated by a technocratic elite. This elite comes from a specialized group of experts from electrical engineering and international corporations, owners of the main electricity companies, for example, ENEL, a multinational company in which the Italian state is still the main shareholder. This has pushed the national technocratic elite to tend to consider social aspects. Continuing with the ENEL example, the following quotation illustrates there was a company decision to environmentally improve projects. This quotation mentions ENDESA instead of ENEL, this is because in 2009, ENEL, an Italian multinational energy Company, bought ENDESA, a Spanish multinational energy company.

"There is a trauma in the company, after 15 months with Bocamina [Thermopower plant] stopped. Clearly the company realised how wrong it was and the need to change its way. Therefore, in the second RCA there is much more influence from ENEL, and for example, we choose to add environmental improvements that were not foreseen in the original project, and that were not in the culture of the Coronel's industry [Coronel is the city where Bocamina is located] nor in the culture of ENDESA (In 2009, ENEL, an Italian multinational energy Company, bought ENDESA, a Spanish multinational energy company.)." [CODE 068, the private sector]

It is important to highlight that this does not mean that the Chilean technocratic elite is totally open to incorporate social and environmental concerns, but more open than the traditional elite. The previous quotation indicates this. The Chilean case has demonstrated that the elite response has been reactive to strong social pressure and the realization that they were unable to solve the conflict with local communities.

\subsubsection{Legal Framework (Regulated or Unregulated Markets)}

As Bauer [62] asserts "rules come before market" because "law and politics establish the rules of the game that include how property rights are defined, what costs and benefits are recognized, to whom they are allocated, how conflicts are resolved, and who gains and who loses". In Chile, rules were made by imposition in the dictatorship, framing the legal structure. Since that period, the private sector completely dominates areas such as water or energy, and policy changes depend on the level of market regulation. Therefore, making changes in a less regulated market is more difficult than making them in a more regulated market because the latter is accustomed to having an observant government. Any change in an unregulated market will mean the need for a strong intervention and political will of the state and more resistance of the economic elite.

Comparing water and energy, water is less regulated. A weak legal framework limits the possibilities of the state to solve conflicts; thus, ordinary courts have been the place where more complex water conflicts have ended up [44]. These are courts in which judges do not have the expertise in water law or policy, "their decisions have typically been erratic, superficial, or incomplete", benefiting more powerful actors [44].

This difference can be seen between water and energy, but also between different energy topics. For instance, changes in energy generation have been more difficult than in transmission and distribution because it is less regulated. Gas has faced a similar situation, as gas is less regulated than other energy sources; therefore, changes have been historically more difficult to make. The Gas Law was originally made in 1932 (Law $\mathrm{N}^{\circ} 323$ ) with its last modification in 1989 (Law $\mathrm{N}^{\circ} 18,856$ ). In the decade up to now, three or four previous bills failed to change the regulation, and it was seen as a sector that was resistant to change. Finally, the Gas Bill, which emerged from the energy policy process, became a law approved in 2016.

\subsection{Social Pressure, the Creation of Public Arenas and Participation in Policy-Making}

How can participative processes led by the government be performed in contexts where it is the private sector which decides the future of a topic? What happens when the government is not needed, but civil society demands to be heard? In the Chilean context, 
this questions the real government capacity to achieve necessary changes. The energy case has demonstrated that changes are possible. However, authoritarian legacies remain as constraints that need to be addressed in order to advance to a transformation of the energy system.

At the government level, the factors mentioned above also explain the different response of the Chilean government to design and develop the two policy processes studied. The energy policy process was structured, with well-defined stages, massive, developed by all the departments of the Ministry and an explicit participation of academia, where formal processes of participation were carried out and outputs were open access. On the other hand, water was less structured, led by a created position in a ministry not related to water issues, and where outputs were not available. Furthermore, although the water policy document identified explicitly the participation of different kinds of actors in its creation, participants of the process do not recognize their participation as a part of a policy process, but as a discussion process where the regional problems were collected. Therefore, participation existed at the discourse level, but not in reality. In terms of implementation and impact of the two policies, the Energy Policy progressed in many areas. Still, others remain with less progress, and several conflicts with local communities also remain active. On the other hand, the impact of the Water Policy was modest.

All the factors analyzed in the previous section have generated a differentiated response in the creation of public arenas in water and energy cases. The energy sector has developed a learning process in the last 10 years. The private sector has tried to create organizations which congregate companies: distribution, generation, natural gas, renewable energy, etc. Dialogue arenas have been developed, such as Energy Scenarios, having an important influence in the design of the energy policy process. These previous dialogue arenas together with a strong social pressure, facilitated the task of the Ministry of Energy, but the leadership capacity of the minister who knew read the context and opportunities, a political will, a compromised ministry team, and budget, among others, allow better results than in water. In the water case, there have been many attempts to develop participatory initiatives to improve water management and governance, mainly at the regional level; however, this has been limited by a weak governance and institutional framework together with the very limited possibilities to make regulatory changes and a lack of political will.

In both water and energy, social conflicts increased in number and magnitude; the main difference is that in energy, local communities and environmental NGOs found a window of opportunity to stop or delay electrical projects through legal actions. Due to the structure of use, these actions impacted the whole system. This created a situation in which the energy sector could not progress; therefore, the only possible way to unlock the crisis was to move the frontiers of what was feasible, allowing the government to reframe their role. In the water case, the only comparable situation was the one faced by the Atacama Region. From the mid-90s to 2012, a significant decline in groundwater levels was observed [69]. The projections showed substantial drops in the water level if the extraction rate did not change, especially in the sectors that supply drinking water [69]. This was a critical situation that put the actors at the same table. However, this was a regional solution, not structural, which the water sector needs. This brings into discussion a question: will the water sector wait for these extreme situations to act and allow structural changes? How much political will is needed?

\subsection{The Water-Energy Nexus}

The water-energy nexus is unique and has recently gained more attention because they are two management systems under an increasing pressure. This pressure results from the tension between power structures, social responses to environmental issues and decisionmaking, and environmental limitations. Climate change intensifies this pressure [62], generating greater vulnerability and conflicts.

An important part of the attention paid in this nexus has been focused on a question of inputs: energy is required for the access, treatment, and distribution of water, and water 
is also necessary not only for the production of hydropower, but also for most generation processes. However, this nexus not only reflects the complexities of two interacting management systems, but also power structures, institutional settings and governance, legal frameworks, vulnerability, socio-environmental conflicts, economic and physical geography drivers.

When viewed together, the governance of these two resources demonstrates shortcomings in the model for national growth and the institutional settings designed to support that growth, demonstrating fundamental issues in the way society is structured for economic growth and the uneven distributions of vulnerabilities that result. For that reason, this is an inflexion moment in which it is important to make decisions beyond a specific sector. A systemic view is required when society is facing systemic problems; or should state and private actors wait for the lack of water or the lack of energy to take action? The water-energy nexus will continue under tension if they wait only for extreme situations to act. We do not include civil society in this question because the water and energy cases in Chile have demonstrated that communities have been the ones who are giving voices of alert because they are facing vulnerabilities in these matters.

The data presented in this article shows an asymmetry in the country's efforts to move towards more sustainable systems. The Chilean case, as the first laboratory of neoliberal state formation [70], has demonstrated the incapacity of markets of self-regulating and the role that state and society must play in order to achieve a governance able to transit to sustainable systems, in which water and energy play a crucial role.

The water sector in Chile is facing a new process of elaboration of a national water policy, proposed by the president and framed by the national water table. There are at least two different strategies to follow. First, a policy formulated from the advice of a small group of experts (business as usual). This strategy has demonstrated a lack of legitimacy and a lack of a long-term perspective. Or second, a process designed from the learnings and lessons of the energy policy process. The government took the first option. Therefore, it is very likely this new process finishes unfruitful, like many others.

From the perspective of sustainable development, the factors related to governance and institutional framework, the conformation of the elite and the legal framework lead to different results and configure different scenarios in terms of conflict over resource use. The energy sector overcame most of the conflicts and is moving fast to a transition to clean energies, aligned with the seventh Sustainable Development Goal "ensure access to affordable, reliable, sustainable and modern energy for all". This transition was unthinkable before the energy policy process. In contrast, these factors became barriers to progress towards sustainable development in the water sector, affecting the water-energy nexus as well.

The incapacity of water institutions and legal framework to tackle water conflicts between multiple users affects the development of the energy sector. Conflicts that involve water and energy are recognized and problematized by national and international organizations. The social perception that the current system favors the interest of large corporations (mainly mining and energy companies) over the needs of regular citizens is spread around the country. The limited role of communities in the governance of their territories will keep water and energy conflicts growing. Therefore, the water-energy nexus is under pressure in Chile. The lack of progress of overcome conflicts and management problems in the water sector intensifies that pressure.

\section{Conclusions}

This article explored the energy and water governance in the post-dictatorial Chilean democracy in order to understand the factors that may influence why the development, impact and inclusion of new voices in public policies related to water and energy differ in Chile, and how that can impact in the water-energy nexus. To end present challenges as temporary to the long-term solutions will require an exhaustive roadmap, beyond the analysis covered in this study in order to simulate a positive rotating socio-economic cycle. 
In relation to the two policy processes, "how participation was understood, configured and incorporated" the government determined two very different policy processes. In the water policy process, participation was limited to mainly consultation, and the process itself was less documented, less transparent and less traceable, which made it more limited than the energy policy process. However, the forcing and differentiating factors of the energy and water sectors help to explain the contrasting results between the two processes. These factors may explain why the water policy has not met its objectives or implemented its actions. As a result, the current government has now set out to develop a new policy. However, progress in this matter is unlikely because the process only considers part of the groups of interest.

A traditional elite that controls the water sector, the degree of deregulation of the water market, and a weak institutional framework seem to be the factors inherited from the dictatorship that strongly influence the failure to generate reforms in the water sector, limiting the path toward sustainable development. As a result, the institutional capacity of the Chilean model is unable to tackle water conflicts. The differences in the structure of use (Where is the resource extracted? Where is the resource used?) and the number of actors who control the sector add complexities to the intricated path of any attempt for water reforms. This not only affects the water-energy nexus, but also the sustainability of the whole system.

The water-energy nexus is under pressure as a result of the tension between power structures, social responses to environmental issues and decision making, environmental limitations and climate change stressors, creating greater vulnerability and conflicts. The governance of these two resources demonstrates shortcomings in the model for national growth and the institutional settings designed to support that growth, revealing fundamental issues in the way society is structured for economic growth and the uneven distributions of vulnerabilities that result.

The Chilean case has demonstrated the fundamental role that the state and society must play, together with the private actors, to determine the actions to achieve sustainable futures. The energy case has demonstrated that changes are possible. However, authoritarian legacies remain as constraints that need to be addressed in order to advance to a transformation of the energy system. The social outbreak in 2019-2020, the referendum for a new constitution, and the composition of elected members of the Constitutional Convention have shown that civil society will continue playing new roles in influencing and changing the political agenda if structural issues remain immutable in Chile.

Governments should learn from the past, otherwise, more conflicts than solutions will continue being the main outcome of the relation between communities, the private sector and the state. This will continue affecting the water-energy nexus. The consideration of factors identified in this article could benefit the success of a policy process. Some of these factors are intrinsic to each sector. Still, others respond to decisions made in the past (in other national contexts). These need to be re-evaluated according to current national and international contexts. A focus on changes and/or transformations of the legal, governance and institutional framework could serve as an example for developing water and energy policies in other countries.

Author Contributions: Conceptualization, R.B. and R.F.; methodology, R.B.; software, R.B.; validation, R.B. and R.F.; formal analysis, R.B. and R.F.; investigation, R.B.; resources, R.B.; data curation, R.B.; writing—original draft preparation, R.B. and R.F.; writing-review and editing, R.B. and R.F.; funding acquisition, R.B. and R.F. All authors have read and agreed to the published version of the manuscript.

Funding: This study was funded by the National Agency for Research and Development (ANID)/Scholarship Program/DOCTORADO BECAS CHILE/2014.

Institutional Review Board Statement: The study was conducted according to the guidelines of the UKRIO's Code of Practice and approved by the Ethical Research Panel, King's College London (protocol code LRS-16/17-3679 and date of approval: 13/October/2016). 
Informed Consent Statement: Informed consent was obtained from all subjects involved in the study. Data Availability Statement: Not Applicable.

Acknowledgments: This study received the support of and is a contribution to the Center Resilience and Climate Research CR2 FONDAP \#1511009. We thank the Department of Geography at King's College London and Frans Berkhout for his support during the PhD of one of the authors of this article. The PhD allows the author to study the energy case deeply. We also thank the interviewees. We would also like to acknowledge and thank the three anonymous reviewers for their constructive feedback and comments for improving this manuscript.

Conflicts of Interest: The authors declare no conflict of interest. The funders had no role in the design of the study; in the collection, analyses, or interpretation of data; in the writing of the manuscript, or in the decision to publish the results.

\section{References}

1. Berkhout, F.; Leach, M.; Scoones, I. Shifting perspectives in environmental social science. In Negotiating Environmental Change: New Perspectives from Social Science; Edward Elgar: Cheltenham, UK; Edward Elgar: Northhampton, MA, USA, 2003 ; pp. 1-31.

2. Meyer, J.M. Political Theory and the Environment. In The Oxford Handbook of Political Theory; Dryzek, J., Honig, H., Phillips, A., Eds.; Oxford University Press: Oxford, UK, 2008; pp. 773-791.

3. Munton, R. Deliberative democracy and environmental decision-making. In Negotiating Environmental Change: New Perspectives from Social Science; Berkhout, F., Leach, M., Scoones, I., Eds.; Edward Elgar Publishing: Cheltenham, UK; Edward Elgar Publishing: Northhampton, MA, USA, 2003; pp. 109-136.

4. International Energy Agency. Energy policies beyond IEA countries, Chile 2018. In Energy Policies beyond IEA Countries; OECD: Paris, France; IEA, International Energy Agency: Paris, France, 2018; p. 191.

5. Carruthers, D. Environmental politics in Chile: Legacies of dictatorship and democracy. Third World Q. 2001, 22, 343-358. [CrossRef]

6. Pessoa, C.; Paley, J. Marketing Democracy: Power and Social Movements in Post-Dictatorship Chile. Lat. Am. Polit. Soc. 2001, 44, 181. [CrossRef]

7. Vergara, J. El mito de las privatizaciones en Chile. Polis Rev. Latinoam. 2005, 4, 1-12.

8. Przeworski, A. Democracy and the Market: Political and Economic Reforms in Eastern Europe and Latin America; Cambridge University Press: New York, NY, USA, 1991.

9. Huneeus, C. Chile: A system frozen by elite interests. In The New International IDEA Handbook; Reynolds, A., Reilly, B., Ellis, A., Eds.; International Intitute for Democracy and Electoral Assistance: Stockholm, Sweden, 2005; pp. 78-81.

10. Delamaza, G. Espacio público y participación ciudadana en la gestión pública en Chile: Límites y posibilidades. Public space and citizen participation in public management in Chile: Limits and possibilities. Polis Rev. Latinoam. 2011, 10, 45-75.

11. Palumbo, B. Marco normativo que permitió la llegada del gas natural a Chile. Regulatory framework that allowed the arrival of natural gas in Chile. In Gas Natural: Lecciones de una Crisis; Domper, M.d.l.L., Cortés, C., Eds.; Ediciones LYD: Santiago, Chile, 2008; pp. 19-52.

12. Ministry of Energy. Política Energética de Chile; Ministry of Energy: Santiago, Chile, 2015.

13. Fuster, R.; Saurí i Pujol, D. El Estado de la gestión integrada de los recursos hídricos en Chile: Estudio de casos en la cuenca del Río Limarí. In Department of Geography; Universitat Autònoma de Barcelona: Barcelona, Spain, 2013.

14. Budds, J. Water, Power, and the Production of Neoliberalism in Chile, 1973-2005. Environ. Plan. D Soc. Space 2013, 31, 301-318. [CrossRef]

15. Bauer, C.J. Slippery property rights: Multiple water uses and the neoliberal model in Chile, 1981-1995. Nat. Resour. J. 1998, 38, 109-155.

16. Bauer, C.J. Bringing water markets down to earth: The political economy of water rights in Chile, 1976-1995. World Dev. 1997, 25, 639-656. [CrossRef]

17. CADE. Informe de la Comisión Asesora para el Desarrollo Eléctrico en Chile; Advisory Commission for Electricity Development: Santiago, Chile, 2011.

18. Bustos-Salvagno, J. Electricity Interconnection in Chile: Prices versus Costs. Energies 2017, 10, 1438. [CrossRef]

19. Gonzalez, G. Proyectos eléctricos y catastro de termoeléctricas en Chile. Electrical projects and thermoelectric register in Chile. In Análisis de Políticas Públicas (APP); Fundación Terram: Santiago, Chile, 2016; p. 40.

20. Larraín, S. Chile necesita una gran reforma energética: Crisis eléctrica, avances y desafíos. Chile needs a great energy reform: Energy crisis, progress and challenges. Energía Equidad 2012, 2, 30-45.

21. Nasirov, S.; Silva, C. Diversification of Chilean Energy Matrix: Recent Developments and Challenges; International Association for Energy Economics: Beijing, China, 2014; pp. 27-31.

22. Romero, H. Ecología política y represas: Elementos para el análisis del Proyecto HidroAysén en la Patagonia chilena. Rev. Geogr. Norte Grande 2014, 161-175. [CrossRef] 
23. El Dínamo. Colbún y Enel Anuncian el fin definitivo de HidroAysen. Colbún and Enel Announce the Definitive end of HidroAysen; El Dínamo: Santiago, Chile, 2017.

24. Fischer, R.; Galetovic, A. Regulatory Governance and Chile's 1998-99 Electricity Shortage; World Bank: Washington, DC, USA, 2001.

25. Sioshansi, F.P. Electricity market reform: What has the experience taught us thus far? Util. Policy 2006, 14, 63-75. [CrossRef]

26. Joskow, P. Introduction to Electricity Sector Liberalization: Lessons Learned from Cross-country studies. In Electricity Market Reform: An International Perspective; Sioshansi, F.P., Pfaffenberger, W., Eds.; Elsevier: Amsterdam, The Netherlands, 2006; pp. 1-32.

27. Ministry of Energy. Energy Agenda, A Challende for the Country, Progress for Everyone; Government of Chile: Santiago, Chile, 2014; p. 125.

28. Bachelet, M. Programa de Gobierno de Michelle Bachelet 2014-2018. Government Programme of Michelle Bachelet 2014-2018; SITEAL: Santiago, Chile, 2013.

29. Pacheco, M. Revolución Energética en Chile; Ediciones Universidad Diego Portales: Santiago, Chile, 2018.

30. Ministry of Energy. Feedback and Deuman, Encuentas Deliberativas Energía 2050; Deliberative Surveys Energy 2050; Ministry of Energy: Santiago, Chile, 2015; p. 68.

31. Ministry of Energy. Politicas Públicas Participativas: La Experiencia de Energía 2050; Division of Foresight and Energy Policy: Santiago, Chile, 2017; p. 61.

32. Ministry of Energy. Licitación de Suministro Eléctrico, Agosto 2016; Chilean Government: Santiago, Chile, 2016 ; p. 12.

33. CNE. Non-Conventional Renewable Energy Generation. 2020. Available online: http://energiaabierta.cl/visualizaciones/ generacion-bruta-ernc/ (accessed on 15 August 2020).

34. Furnaro, A. Neoliberal energy transitions: The renewable energy boom in the Chilean mining economy. Environ. Plan. E Nat. Space 2020, 3, 951-975. [CrossRef]

35. Bloomberg New Energy Finance. Climatescope Emerging Markets Outlook Energy transition in the World's Fastest Growing Economies; Bloomberg New Energy Finance: London, UK, 2018; p. 66.

36. Emol. Presidenta Bachelet agradece a generadoras y celebra que Chile tendrá "desarrollo descarbonizado". President Bachelet thanks generators and celebrates that Chile will have "decarbonized development". Mercurio 2018. Available online: https: / / www.emol.com/noticias/Economia/2018/01/31/893366/Presidenta-Bachelet-agradece-a-generadoras-y-celebraque-Chile-tendra-desarrollo-descarbonizado.html (accessed on 30 September 2020).

37. Ministry of Energy. Plan de Descarbonización de la Matriz Eléctrica. Decarbonisation Plan of the Electricity Matrix. 2019. Available online: https://www.energia.gob.cl/mini-sitio/plan-de-descarbonizacion-de-la-matriz-electrica (accessed on 30 September 2020).

38. Chilvers, J.; Longhurst, N. Participation in Transition(s): Reconceiving Public Engagements in Energy Transitions as Co-Produced, Emergent and Diverse. J. Environ. Policy Plan. 2016, 18, 585-607. [CrossRef]

39. OECD. Environmental Performance Reviews: Chile 2005; Organisation for Economic Co-operation and Development (OECD): Paris, France, 2005.

40. World Bank. Diagnóstico de la Gestión de los Recursos Hídricos. Diagnosis of Water Resources Management Models in Chile; Departamento de Medio Ambiente y Desarrollo Sostenible Región para América Latina y el Caribe, World Bank: Washington, DC, USA, 2011.

41. Rivera, D.; Godoy-Faúndez, A.; Lillo, M.; Alvez, A.; Delgado, V.; Gonzalo-Martín, C.; Menasalvas, E.; Costumero, R.; GarcíaPedrero, Á. Legal disputes as a proxy for regional conflicts over water rights in Chile. J. Hydrol. 2016, 535, 36-45. [CrossRef]

42. Chilean Government. National Water Policy; Presidential Delegation for Water Resources; Ministry of Internal Affairs and Public Security: Santiago, Chile, 2015; p. 104.

43. Larraín, S.; Poo, P. Conflictos por el Agua en Chile, Entre los Derechos Humanos y las Reglas del Mercado. Water Conflicts in Chile: Between Human Rights and the Market Rules. 2010. Available online: http://www.archivochile.com/Chile_actual/patag_ sin_repre/03/chact_hidroay-3\%2000026.pdf (accessed on 19 June 2019).

44. Bauer, C.J. Water Conflicts and Entrenched Governance Problems in Chile's Market Model. Water Altern. $2015,8,147-172$.

45. DGA. Limitaciones y Restricción al Uso del Agua; General Water Directorate (DGA): Santiago, Chile, 2020.

46. INDH. Mapa de Conflictos Socioambientales en Chile, 2015. Map of Socio-Environmental Conflicts in Chile, 2015; INDH: Santiago, Chile, 2015.

47. Prieto, M.; Fragkou, M.C.; Calderón, M. Water Policy and Management in Chile; Wiley: Hoboken, NJ, USA, 2020; pp. 1-11.

48. LADB Staff. Movement to Nationalize Water Gains Ground in Chile. In UNM Digital Repository; University of New Mexico: Albuquerque, NM, USA, 2009.

49. Ministry of Internal Affairs and Public Security. Decreto 899 Designa a Don Reinaldo Ruiz Valdés como Delegado Presidencial para los Recursos Hídricos. Decree 899 Appoints to Reinaldo Ruis Valdés as Presidential Delegate for Water Resources. In Decree 899; Ministry of Internal Affairs and Public Security: Santiago, Chile, 2014.

50. Presidential Delegation for Water Resources. Informe de Gestión de la Delegación Presidencial para los Recursos Hidricos; Ministry of Internal Affairs and Public Security: Santiago, Chile, 2015.

51. Presidential Delegation for Water Resources. Responde a la Solicitud de Información $N^{\circ}$ AB001W0003522; Ministry of Internal Affairs and Public Security: Santiago, Chile, 2015.

52. President of Chile. Discurso presidencial del 21 de Mayo; Chilean Government: Santiago, Chile, 2016.

53. Regional Government of Arica and Parinacota. Mesa de Trabajo Busca Optimizar los Recursos Hídricos de Arica y Parinacota; Regional Government of Arica and Parinacota: Arica, Chile, 2014. 
54. FM Plus. Delegado Presidencial de Recursos Hídricos Visitó la Región Para Conformar Mesa Pública del Agua; FM Plus: Antofagasta, Chile, 2014.

55. El Quehaydesierto. Intendente Vargas Encabezó la Constitución del Consejo Regional de Recursos Hídricos; El Quehaydesierto: Copiapó, Chile, 2014.

56. El Ob-servatodo. Mesa Provincial del Recurso Hídrico Compromete Nuevas Acciones para Hacer Frente a la Sequía; El Observatodo: Coquimbo, Chile, 2014.

57. El Liguano. Gobernador de Petorca Junto al Intendente Aldoney Instalan Mesa de Trabajo Transversal para Desarrollar una Politica Regional del Recurso Hidrico; El Liguano: La Ligua, Chile, 2015.

58. Ministry of Agriculture. Delegado Presidencial Instaló Mesa Territorial del Agua en el Maule; Ministry of Agriculture: Talca, Chile, 2014.

59. Soto, N. Delegado Presidencial Participó de la Conformación de Mesa Comunal del Agua en Ancud; SoyChiloe: Chiloe, Chile, 2014.

60. The Chilean Congress. Boletín $N^{\circ}$ 13191-12. Comisión de Medio Ambiente y Bienes Nacionales. $2021 . \quad$ Available online: https://tv.senado.cl/tvsenado/comisiones/permanentes/medio-ambiente/comision-de-medio-ambiente-y-bienesnacionales/2021-05-24/200639.html (accessed on 15 March 2021).

61. Ministry of Public Works. Mesa Nacional del Agua. National Water Table. 2019. Available online: https://www.mop.cl/ MesaAgua/index.html (accessed on 7 April 2019).

62. Bauer, C.J. Dams and markets: Rivers and electric power in Chile. Nat. Resour. J. 2009, 49, 583-651.

63. University of Chile. Informe Final: Diagnóstico Nacional de Organizaciones de Usuarios; Laboratorio de Análisis Territorial, Universidad de Chile: Santiago, Chile, 2018.

64. World Bank. Chile, Estudio Para el Mejoramiento del Marco Institucional Para la Gestión del Agua; World Bank: Washington, DC, USA, 2013.

65. Porket, J.L.; Parry, G. Political Elites. Br. J. Sociol. 1970, 21, 232. [CrossRef]

66. Dahl, R.A. Democracy and Its Critics; Yale University Press: London, UK, 1989.

67. Vergara, L.G. Elites, political elites and social change in modern societies. Rev. Sociol. 2013. [CrossRef]

68. Carrière, J. Conflict and cooperation among Chilean sectoral elites. Bol. Estud. Latinoam. Caribe 1975, 19, 16-27.

69. DGA. Informe Final: Actualización de la Modelación Integrada y Subterránea del Acuífero de la Cuenca del Río Copiapó; General Water Directorate: Atlas del Agua, Chile, 2013; p. 245.

70. Harvey, D. A Brief History of Neoliberalism; Oxford University Press: New York, NY, USA, 2005. 